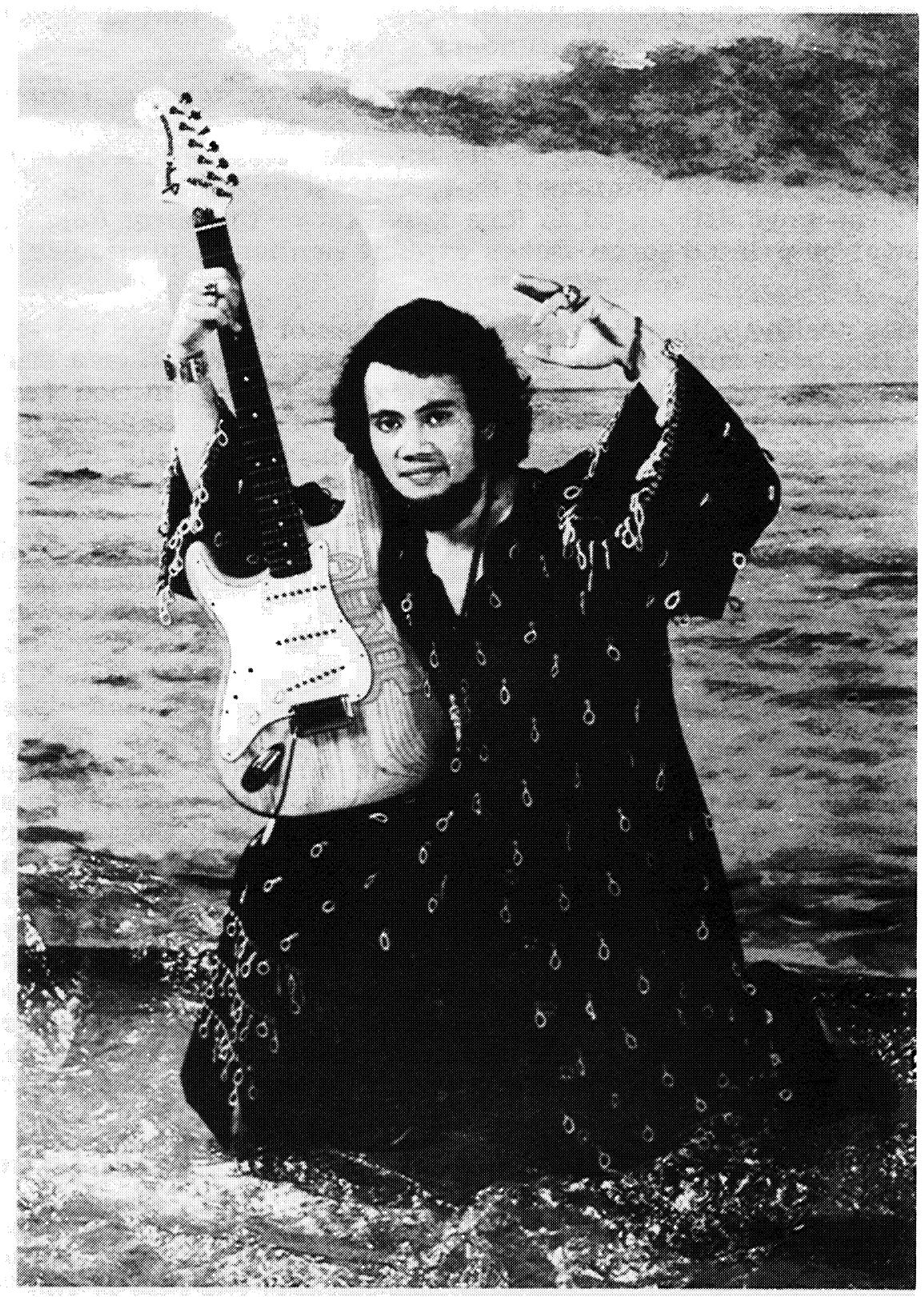

Rhoma Irama 


\title{
RHOMA IRAMA AND THE DANGDUT STYLE: ASPECTS OF CONTEMPORARY INDONESIAN POPULAR CULTURE ${ }^{1}$
}

\author{
William H. Frederick
}

Everywhere in the world People are playing music All kinds of music From pop to classical

If you are anti-dangdut Hate it but don't make trouble Just leave us alone to sing Sing our Melayu songs
Di mana mana di atas dunia Banyak orang bermain musik Bermacam-macam warna jenis musik Dari pop sampai yang klasik

Bagi pemusik yang anti-Melayu Boleh benci, jangan mengganggu Biarkan kami mendendangkan lagu Lagu kami lagu Melayu

\section{Rhoma Irama ${ }^{2}$}

Dangdut, the style of music here defended by contemporary Indonesia's bestknown popular entertainer, has been of enormous influence in much of the postSukarno period, especially the years 1975-1981. Aimed directly at youth, it is dominated by a pulsating dance rhythm, and a populist message, with both Islamic and secular variants. It has produced Indonesia's first true entertainment superstars; ${ }^{3}$ played a large role in creating a market for the mass media in Indonesia (not only cassette tapes but radio, movies, and television); made a mark on other areas of cultural activity, especially literature; sparked open and often heated debate over the state of Indonesian culture; and given Indonesian Islam a new kind of public identity. And while dangdut has been criticized on various grounds, it has been

1. Most of the research for this paper was undertaken with the generous support of the Fulbright Research Fellowship Program and Ohio University's Research Council, Baker Fund Committee, and Southeast Asian Studies Program. I am grateful for their confidence and financial aid. For their kindness on many occasions I want especially to thank $\mathrm{H}$. Misbach Yusa Biran and the Sinematek staff, Rhoma Irama and the Soneta Group, P. T. Yukawi, Mus Mualim, Titiek Puspa, and Salim Said. For the kind of probing of earlier versions of this paper that only the best of colleagues can give, I want to thank John Smail, Don Emmerson, Bill Liddle, Ben Anderson, and Marty Hatch. None, of course, is responsible for the errors and wrongheadedness that remains.

2. "Musik," from Gitar Tua Oma Irama, sound track from the film (Cassette, Yukawi, 1977?).

3. By "superstar" I mean not only an important and recognized figure, but one who is clearly significant beyond a relatively small economic or intellectual elite, to a genuinely mass audience. There have been entertainment "stars" for many years in Indonesia, but it is only relatively recently that superstars have become a possibility from the point of view of economics and technology. 
notable for the number and devotion of its fans in cities as well as villages throughout the archipelago.

Yet this phenomenon remains largely unexplored by those who customarily watch Indonesia closely. In a recent collection of studies on modern Indonesian culture, for example, dangdut receives not a single mention. ${ }^{4}$ Indonesian intellectuals--even those who write with considerable flair about pop novels, film, comics, and even graffiti--are generally incredulous if anyone takes a serious interest in this style of music. ${ }^{5}$ Dangdut musicians and devotees have themselves been slow to examine critically the genre they invented and nurtured. ${ }^{6}$ Why this should be so is not entirely clear, but it does seem to be the case that Western scholars of culture in the developing world have been attracted to what are more properly described as the folk arts rather than to the modern, "pop" ones, and to the plastic or literary arts rather than to music ; ${ }^{7}$ Indonesian scholars, many of them trained in the universities of the West, have also tended to look on dangdut as merely faddish and cheap.

Yet I believe that dangdut constitutes not only a legitimate part of contemporary Indonesian culture (as opposed, for example, to being a thoughtless rip-off of Western styles), but a sensitive and useful prism through which to view Indonesian society. These characteristics, furthermore, are particularly attractive where New Order Indonesia is concerned, the nature and social underpinnings of which have on the whole proved remarkably difficult to describe accurately. Conventional data, for example, tell us relatively little about such things as Indonesian populism, popular views of national character, or Islam in everyday life. An examination of dangdut, however, has much to offer on such subjects. While it would be absurd to argue, as Albert Goldman has attempted to do in his recent biography of Elvis Presley, that we can find in a single recording star a microcosm of national life, dangdut's chief practitioner reveals much about contemporary Indonesia through his life story as well as his ideas.

4. Gloris Davis, ed., What Is Modern Indonesian Culture? Papers in International Studies Southeast Asia Series No. 52 (Athens, Ohio: Ohio University, 1979).

5. To my knowledge, no formal essays or books on dangdut have appeared in Indonesia, although there have been some writings (ranging from serious to tongue-incheek) in newspapers and popular magazines. Music is perhaps the least-discussed of the popular arts. See, for example, the collection of pieces entitled "Kebudayaan Pop: Komersialisasi Gayahidup,"Prisma, 6, 6 (June 1977), or Umar Kayam, Seni, Tradisi, Masyarakat (Jakarta: Sinar Harapan, 1981).

6. On March 10-11, 1982, the Yayasan Musik Melayu Indonesia (Yammi), a group formed in May 1980, held its first workshop on dangdut, spurred on perhaps by the apparent recent decline in the music's popularity and sales power. Tempo, 12, 3 (March 20, 1982), p. 26. On Yammi's founding see Terbit, May 10, 1980.

7. Modern "pop" music, fairly constantly examined in the West for what it reveals about social context and trends, seems to hold relatively little interest for students of the non-Western world. Research on non-Western urban and popular modern music has been quite limited, and many of the reasons for this are discussed most cogently by Bruno Nettle in his introduction to Eight Urban Musical Cultures: Tradition and Change (Urbana: University of Illinois Press, 1978). The problems and rewards of such research are evident C. Geijerstan, Popular Music in Mexico (Albuquerque: New Mexico University Press, 1976), one of a very small number of booklength studies.

8. Albert Goldman, Elvis (New York: McGraw Hill, 1981). 
The Origins of Dangdut

The term "dangdut" dates only from about 1972 or 1973 , but the music it describes onomatopoetically and with a certain derogatory feeling--the word translates roughly as "thumpety-thump" from the characteristic dxumbeat--has a long and complicated genealogy. ${ }^{9}$ Both in social spirit and instrumentation dangdut reaches back into the early colonial period, when a potpourri of Indonesian, Arab, and Western instruments were played together in the tanjidor, small wandering orchestras typical of Batavia. ${ }^{10}$ In the course of the nineteenth century other influences were absorbed. By the 1820s the Batavian Chinese ensemble known as gambang kromong appeared, mixing Chinese, Sundanese, Maluku, and Portuguese instruments and melodies; somewhat later most of the elements of the well-known kroncong music were heard together. ${ }^{11}$ This musical style acquired in the early twentieth century a large and varied repertoire, as well as a somewhat unsavory social reputation. Kroncong vocalists and players, who customarily wandered about Java's cities in the fashion of the old tanjidor and in some areas associated themselves with the world of stamboel and other budding forms of popular urban drama, were widely viewed by the upper classes--Eurasian and Indonesian, to say nothing of Dutch--as disreputable products of kampung (lower-class neighborhood) life. ${ }^{12}$ They became known derisively as buaya kroncong (kroncong "crocodiles" or toughs), werklozen (unemployed, but in the sense of bums), and klootzaken (literally scrotums, but in the sense of "s.o.b.'s" or "real jerks"). ${ }^{13}$ In the 1920 s Indonesians with some claim to prominence in the colonial order began to look more kindly on kroncong, but they continued to regard it as distinctly "lower class" (kampungan) and rather distastefully emotional and egalitarian. ${ }^{14}$

In the $1930 \mathrm{~s}$, after the advent of radio, the phonograph, and moving pictures, kroncong music made an important transition. In the early part of the decade a

9. There is general agreement that dangdut--now and then, with conscious Javanese humor spelled "dhank dhut"--was indeed a term of derision originating among urban intellectuals who thought the new music so much childish banging. Singers like Oma Irama, however, made a point of accepting the name with a certain defiant pride and antielite feeling.

10. Mona Lohanda, "Majoor Jantje and the Indische Element of Batawi Folkmusic" (Paper presented to the Third Dutch-Indonesian Historical Congress, Leiden, June 23-27, 1980), pp. 12-13.

11. Discussion with H. Misbach Yusa Biran, Jakarta, August 27, 1979. On kroncong, see especially Ernst Heins, "Kroncong and Tanjidor: Two Cases of Urban Folk Music in Jakarta," Asian Music, 7, 1 (1975), pp. 20-32; and Bronia Kornhauser, "In Defense of Kroncong," in Studies in Indonesian Music, ed. Margaret J. Kartomi (Clayton, Victoria: Monash University, Centre of Southeast Asian Studies, 1978), pp. 104-83.

12. Although villages are sometimes called kampung, I am using the term here in its common and specific sense of an urban neighborhood, which in colonial times meant a crowded, Indonesian-inhabited area ringed by asphalted roads and the Western-style city, and bearing some of the attributes of a slum. While kampung contained persons from a variety of economic and social classes, in general the upper class lived outside or in particular kampung with reputations for being relatively wealthy and progressive.

13. Discussion with H. Misbach Yusa Biran, Jakarta, August 27, 1979.

14. Kusbini, "Kroncong Indonesia," Musica [Jakarta], 1, 1972, p. 28. 
number of serious efforts had been made to create a thoroughly "Indonesian" film that would appeal to a mass audience. One of the keys turned out to be kroncong melodies, which dominated the film Terang Boelan (1937) and, it is generally acknowledged, did much to make the film an enormous box-office success. By placing the kroncong songstress Miss Rukiah opposite actor Raden Mochtar and emphasizing a sweet, romantic, melodic line with simple pantun lyrics, the movie's producers broke through the limitations of the widely perceived elitism in the Hawaiian-style musicals of the day and in the largely foreign (European or Chinese) atmosphere of other productions. ${ }^{15}$ Nor were the sociopolitical implications of all this lost on Indonesian nationalists. Dr. A. K. Gani of the Partai Serikat Islam Indonesia (PSII) and, later, Gerindo, was one of the first to see the possibilities in cinema and music for reaching the uneducated masses with nationalist ideas. He not only took a leading role in a film (playing a medical doctor with a nationalist mission), but in 1938 organized a kroncong festival with the goal of commemorating the famous Youth Oath ten years earlier and of elevating kroncong to the level of a "national music." 16 If the latter project did not succeed as Dr. Gani had hoped, kroncong and the kroncong sound did become strongly identified in the public mind with a certain earthy camaraderie and an obviously Malay, as opposed to Western or Chinese, character. For this reason as much as any other, kroncong and related groups came to be known in the 1940s by the generic term orkes Melayu, a designation still in use.

During the Japanese occupation and the revolutionary period kroncong music and its derivatives held their own against, and sometimes blended with, the nationalist marches and fighting songs appropriate to those times. But in the 1950 s the old-style harmonies gradually gave way to experimentation with a modernized Melayu sound much influenced by Western orchestration and samba and rhumba beats. General Rudi Pirngadie (1918-73), sometimes known as "General Kroncong" for his leading role as a composer and orchestra leader, attempted to fashion from kroncong elements "a music that was a concrete symbol of nationalist ideology"; ${ }^{17}$ Ismail Marzuki (1914-58), the son of a shop worker and formally educated only to the junior high school level, bridged the colonial and independence periods by creating a synthesis of traditional sentimentality and modern (Western) instrumentation and timing. For many Indonesians, his compositions represented Indonesian music's best effort yet at being up-to-date and "international."

By the $1960 \mathrm{~s}$, however, a reaction--largely politically driven--had begun to set in. Modernized kroncong frequently seemed, in the atmosphere of Guided Democracy, more bourgeois and foreign-inspired than simply mellow and contemporary; musicians began searching for a more obviously indigenous and less sweet flavor. They found it in the orkes Melayu tradition, which had continued to develop, far from the capital and its music critics, largely in the Medan and Padang regions. ${ }^{18}$ So-called Melayu-Deli songs were credited with making a financial hit of the Malayaborn P. Ramlee's film Diuwita (1952, but circulated in Indonesia later) and were an

15. On Terang Boelan see Salim Said, "Perfilman di Indonesia, Sebuah Tinjauan Historis Sosiologis" (Skripsi Sarjana Sosiologi, Universitas Indonesia, 1976), pp. 38-44. Also H. Misbach Yusa Biran, "Pasang Surut Perkembangan Film Indonesia," Ikhtisar Bahan Ceramah 30 Juni 1976 di Taman Ismail Marzuki (Jakarta: mimeo, 1976), p. 1 .

16. Misbach, "Pasang Surut," pp. 3-4; on Dr. Gani's film career see Soeara Oemoem, February 22 and $26,1941$.

17. Kornhauser, "In Defense of Kroncong," pp. 136-37.

18. On Melayu music in general see John D. Goldsworthy, "Melayu Music of North Sumatra: Continuities and Change" (Ph.D. dissertation, Monash University, 1979). 
important part of subsequent productions in which Ramlee sang his own compositions amid settings such as villages and poor urban neighborhoods. ${ }^{19}$ Said Effendi drew on similar sources of inspiration for the musical film Serodja (1959), for which he wrote the music and provided a fine performance as both singer and actor. From that point on, Said Effendi's star began to rise rapidly, along with those of other composers and singers such as A. Chalik, Husein Bawafie, and Husnah Thahar. They were joined by a young performer named Ellya (b. 1938). ${ }^{20}$ A native Jakartan, she evolved a powerful singing style that was loyal to the orkes Melayu product but punctuated it with a new rhythm and texture of sound (particularly those made on Indian, Arab, and Indonesian drum-, flute-, and lute-like instruments) borrowed in large part from the musical scores of the Indian films that flooded Indonesian theaters at the time. Ellya infused a unique dynamism and sensuality into her music, and her throbbing rendition of Husein Bawafie's lyrics to "Boneka dari India" (1956) can with some justice be referred to as the first dangdut song, though that term had not yet been coined. ${ }^{21}$ Predictably, Ellya entered films, and for several years the "Melayu sound" attracted a sizable following. If it did not always thrill educated, upper-class society, whose tastes seemed to remain tuned to the international music world, this Melayu sound does seem to have satisfied some of the ideological needs of the time by being vaguely populist (merakyat) and by offering an alternative to Western pop music, a good deal of which had in the 1960 s been branded by leftwing and nationalist groups as decadent and unsuitable for Indonesia. ${ }^{22}$

With the debacle of 1965, developments in Melayu music were overwhelmed by a wave of Western pop, rock, and country music that rushed in to fill the vacuum created by the pre-1965 official stance against pop imports. Well before New Order Indonesia was opened to Western economic activity, it was opened to American and British rock music. The distinctive mixture of sounds produced by various sorts of drum (gendang), lute (gambus), bass, harmonium, bamboo flute (suling), and guitar gave way to modern, and often electrified, Western ones; bands played imitations of foreign hits on records that could now be freely bought and listened to.

19. Diuwita played for three straight months at one Yogyakarta theater, a feat probably never matched since by an Indonesian film. S. B. Tono, "P. Ramlee, S. Effendi, dan Oma Irama, Tiga Nama yang Perlu Dicatat," Kedaulatan Rakyat, September 23, 1978. On Ramlee, see Christian Pelras, "P. Ramlee: Portrait d'un Artiste Malais," Archipel, 5 (1973), pp. 243-50.

20. Ellya came from a middle-class family and was educated at a madrasah or Islamic school. Married five times, she has recorded under the names Ellya Alwi (her family name), Ellya Agus, Ellya M. Haris, and Ellya Khadam.

21. Apa dan Siapa: Sejumlah Orang Indonesia (Jakarta: Grafitipers, 1981), p. 145, cites an unnamed periodical article to this effect.

22. Much of Western popular culture was pronounced morally unacceptable by Lekra (Lembaga Kebudayaan Rakyat), a cultural organization founded in 1950, but which became a powerful arbiter of cultural style and life only in the early 1960s. See Yahaya Ismail, Pertumbuhan Perkembangan dan Kejatuhan Lekra di Indonesia (Kuala Lumpur: Dewan Bahasa dan Pustaka, 1972). I can recall clearly how, in Jakarta in 1964, university students often paid lip service to the attraction of orkes Melayu music, but at home (behind closed doors and blinds!) played that hard-toget Beatles record over and over again. This was the period in which Sukarno jailed the Koeswoyo Brothers, whose original band, Koes Bersaudara, played Western rock. 
Rhoma Irama and the Dangdut Style

In the late $1960 \mathrm{~s}$, bands which had for a few years satisfied themselves and their limited, urban elite audiences with more or less literal translations of hits by the Everly Brothers, Elvis Presley, the Beatles, and the like--one thinks of groups like Koes Plus, Mercy's, Panbers, and Bimbo--began to make cautious innovations. Basically, they incorporated select elements of the Melayu-Deli and kroncong traditions into their work. The effort produced a fairly slick, contemporary sound, and a number of singers, such as Hetty Koes Endang, Broery Pesolima, Titi Qadarsih, and Emilia Contessa, showed a genuine flair for it. Although pleasant to the ear, this synthesis lacked a certain spark of originality; its melodies and lyrics exuded an upper- and upper-middle-class aura. Wags soon dubbed the music "Melayu Mentengan," after the swank residential district in Jakarta, ${ }^{23}$ and the lukewarm public response to a "modernized" arrangement by the D'Lloyds group of the title song from the old movie Serodia seems to have made the point that one could not capture new audiences simply by recycling old hits, Western or indigenous.

As it happened, at least one young man had come to precisely this conclusion as early as 1969 , when he sat in the then less-than-fashionable Jakarta satellite of Tebet, attempting to fashion a "new music" with which to replace the Western rock he had just renounced. His odd name was Oma Irama, invented by his parents to commemorate the special circumstances surrounding his birth: his mother had gone into labor upon returning home from an outdoor concert and thus the child was called irama or "rhythm." 24 Originally there was little to suggest that this fellow, who grew to be a mediocre student with a penchant for rock music and, it is said, rather rakish behavior, would turn out at all differently from so many other urban middle-class youths.

But in less than a decade Oma, who subsequently styled himself Rhoma by adding the initial letters of the titles raden and haji to his childhood nickname, was transformed--or perhaps transformed himself--into one of the best-paid and most widely recognized contemporary Indonesians, and a musician who changed the face of Indonesian music. While his accomplishments stand on their own, it is also true that his biography has fascinated Indonesian society at many levels for some time. The reason for this interest appears to be that Rhoma Irama's life exemplifies a partly traditional and partly very contemporary kind of rags-to-riches, triumph-ofthe-good-individual story that young Indonesians find very appealing. And it is perhaps true as well that the details of this personal tale, especially in romanticized screen versions, mirror the popular perceptions, frustrations, and desires of the times with remarkable coherence.

Rhoma was born on December 11, 1947 in Tasikmalaya, West Java. His father, a captain in the army, moved the family to Jakarta in the early 1950s and hoped the boy would take advantage of the educational facilities in the capital city to become a doctor. Rhoma's mother, a native of Bandung, was perhaps a little less insistent about the precise career choice, but there can be little doubt that she too had middle-class aspirations for her son. When her husband died in 1957, she continued

23. Tempo, 5, $3($ March 22,1975$)$, p. 45.

24. Here and henceforth I have relied on the following sources for information on the life of Oma Irama: A pa dan Siapa Orang Film Indonesia, 1926-1978 (Jakarta: Yayasan Artis Film/Sinematek, 1979), p. 365; Apo dan Siapa: Sejumlah Orang, pp. 234-36; and personal interviews with Oma Irama in Jakarta in October 1978 and August 1980 . 
to follow their earlier plans for Rhoma's education; despite help from a brother in Bandung, it was no easy task, financially or otherwise.

A restless boy, Rhoma seemed moved by music and little else. He is said to have drummed on his school bench with such verve that his classmates stopped to listen. He taught himself to play the guitar and practiced singing in his naturally clear, full-toned voice. In his early teens he played, without his mother's or uncle's knowledge, in a number of bands formed by school chums in Tebet. In 1963 he established his own band, Gayhand, attempting to make a paying business out of a repertoire of Beatles music and tunes associated with Paul Anka, Tom Jones, and Andy Williams. It was neither a creative nor a commercial success, at least not on the scale Rhoma had hoped for. But educational plans, his mother had finally to admit, had not worked out very well either. Rhoma moved desultorily through a number of high schools in Jakarta and elsewhere, and then attended Universitas 17 Agustus before finally giving up. He felt himself to be a musician and began to discover within himself a gritty determination to make the world take notice.

It is difficult to say exactly how the change took place, but rather abruptly Rhoma turned to Melayu music as an alternative to Western pop and rock. More likely than not, the young man's still-developing musical and business intuitions were equally aroused. In 1968 he sang for a while with the Orkes Melayu Purnama. He was impressed with both the spirit and the marketability of the band's style, and there he met the singer Elvy Sukaesih (b. 1951), who had already developed a fluid approach to Melayu music that was new and exciting. By his own account, this experience, together with the excitement of reaching an audience larger and different in social composition from those he was used to, propelled Rhoma into planning a new musical style with certain specifications: it must be broadly popular, cutting across class lines and appealing to the sensibilities of Indonesians of all sorts; it must be unmistakably modern; and it must carry a message, however simple, in a language that was easily grasped by young people everywhere. Finally, this new music must neither reveal an obvious kinship with Western styles--the goal was an unmistakably "Indonesian" or at least an "Eastern" sound--nor merely imitate the existing Melayu-Deli style with its Arab and Indian flourishes. ${ }^{25}$

This was a tall order by any reckoning, and a music to fill it did not appear overnight. But that such a music was envisioned--and envisioned in this particular fashion--reveals much about Oma Irama that might otherwise be obscure. One is struck, for example, with the deliberate, intellectualizing approach he took toward his music at this early stage. There is no reason to disbelieve his own account of the manner in which he sat down to ponder how a new style might be created. While the eventual difference between success and failure in this endeavor undoubtedly owes as much to intuitive creative talent as to deliberation, it is the studied character of Oma's search that first invites attention. In addition, his actions bear the unmistakable stamp of a shrewd pragmatism and natural business acumen. Today Oma frequently disavows having had any special concern for the potential financial rewards offered by public entertaining, but the reality is surely rather different. He seems instinctively to have identified popular success at least partly with commercial success, and has more recently shown that he has an unerring business sense. He sees nothing contradictory, and certainly nothing morally objectionable, in aspiring to be entrepreneur and artist, and has applied his keen feel for the public pulse to both enterprises.

25. Here and elsewhere I have taken care to avoid putting words in Oma Irama's mouth, and drawn as directly as possible from the interviews noted above. 
Following a brief period of trial and error, during which he struggled to carry out some of his ideas with ensembles he did not control (all of them orkes Melayu of the usual sort), Oma formed Soneta in 1971. This group was still basically an orkes Melayu, and was frequently advertised as such during its early years, but the intent seems always to have been to break out of the orkes Melayu pattern. Later the name Soneta Group, with its contemporary ring and affinity with the titles of diversified New Order enterprises (Sinar Group, Kartini Group), was insisted upon. Soneta gave Oma both creative elbowroom and a certain degree of financial independence with which to experiment. He had mastered the Melayu sound and, with Elvy Sukaesih as his principal singing partner, rode the vogue as he began to infuse it with new ideas. There was no musical revolution, but a gradual and not always certain development produced by an active musical imagination and the competition and financial rewards of the musical marketplace. Melayu tunes were already growing in popularity again--perhaps they seemed fresh and catchy to a new generation. Oma was not responsible for this trend, but he did realize that he could seize the essence of the music itself and the opportunity offered by its new recognition to create something fresh and exciting.

To speak of a well-defined Soneta Group style between 1971 and about 1974 would be to ascribe to the compositions it played a coherence that they did not, if available recordings are faithful, in reality possess. At most it might be said that Oma and Elvy managed to vary the instrumentation and phrasing of their numbers to produce more variety in tone and texture than displayed by the ordinary orkes Melayu. The typical underbeat of this music was also treated in such a way as to give it more verve and expressiveness than its Indian model. Oma's output as a composer, however, was limited, and as a lyricist his work showed little depth or direction. ${ }^{26}$

By 1975, however, the outlines of a tighter synthesis and a patently individual personality could be seen in Oma's music. It was above all an energetic style that pumped the Melayu song full of a liquid, flowing rhythm and highlighted its characteristic waves of melody. In part the effect was achieved with subtle changes in orchestration, but it came more noticeable with the incorporation of electrical instruments--guitar, organ, even mandolin--and increasingly powerful acoustical equipment. This kind of music could be felt in an almost visceral way. If Melayu music was customarily foot-tapping stuff, then this dangdut (as it was now being called) practically shook young listeners, compelling them to toss off their footgear and rock (bergoyang) to the music. Indeed, dancing in this particular manner, a cross between the traditional kampung-style joget and vaguely rock-and-roll motions, became a hallmark of Soneta performances. Oma and Elvy invited the audiences to enjoy themselves and move with the music:

Let's dance, hey, let's dance

Come on, hey, dancing's great

Rock away, swing those hips

Rock away, swing those hips

With a happy heart

Enjoy yourself, enjoy....
Mari joget, hai, kita berjoget

Duhai asyik, hai, kalau berjoget

Bergoyang-goyang (yang)

Pingguli goyang (yang)

Bergoyang-goyang (yang)

Pingguli goyang (yang)

Hati gembira, bersuka ria. . . ${ }^{27}$

26. See, for example, the numbers "Ke Bina Ria," from Orkes Melayu Oma Irama Ke Bina Ria (Casette, Indah Record, 1973-74?), and "Ke Pasar Minggu" and "Nona Manis" from Orkes Melayu Oma Irama Ke Pasar Minggu (Cassette, Indah Record, 1974?). On both tapes we are offered only two songs by Oma, the remainder being compositions written and performed by Ellya and others.

27. "Joget," Album I/ Oma Irama (Cassette, Disco Records [Remaco], 1975?). 
One of the unusual qualities of this music was the way it was constructed, especially the role taken by the drum and the new function given to the breaks, so as to throw particular attention onto the words of each composition. ${ }^{28}$ As a lyricist, Oma began to develop a distinctive talent; his writing was direct and simple, employing a stripped-down but lively and current vocabulary. He also began to move beyond the pantun form to convey an extended story or emotion. In the beginning these verses dealt with love, disappointment, moonlit nights, and the like, themes in the old Melayu romantic vein; later they slipped into what musician and critic Remy Sylado once called the "Why-oh-why?" variety of hand-and heart-wringing typical of the Western-influenced pop of the time. ${ }^{29}$ But on occasion there appeared nicely wrought stories (as in "Cincin Kawin," in the course of which the boy persuades the girl to marry him), a subtle humor which meshed with the music in an unusual way (as in "Kroncong Melayu," done kroncong style but always seeking to break out into dangdut), and rather shocking (for the genre) topics such as anger (e.g., in "Bosan," which includes the lines "I'm tired of looking at you! . . . Go away and don't come back!"). ${ }^{30}$

It is difficult to say why the fans of the day attended to these lyrics, as opposed to simply drinking in the sound, but it is apparent that they did. Many who participated in the performances suggest that there was something novel and exciting in having lyrics tell a tale or express a feeling in standard Indonesian and in a vocabulary that even youths with little schooling could understand. ${ }^{31}$ It also seems likely that young people listened because the experiences and emotions Oma expressed in his songs were familiar and realistic--precisely what he had intended. While it cannot fairly be maintained that dangdut by 1975 exhibited an obvious message or mission, words were already important. Oma, sensing a communicative spark in the air, placed increasing emphasis on his lyrics and gave careful thought to what his songs had to say. ${ }^{32}$ He did not abandon altogether the "Hey, let's dance!" number or light, romantic compositions, but he did begin to work out ways of mixing medium and message. He noticed, for example, that young people frequently remembered his lyrics and, to satisfy as well as enhance this interest, he soon began to insist that his tapes be produced with printed inserts setting the lyrics down in black and white. ${ }^{33}$

A final characteristic of the Soneta formula deserves mention: theater. Borrowing from what he understood of American and British hard-rock band shows--and

28. Tempo, 5, 3 (March 22, 1975), p. 47.

29. Remy Sylado, "Musik Pop Indonesia: Satu Kebebalan Sang Mengapa," Prisma, 6, 6 (June 1977), pp. 23-31.

30. These three songs are from Album II.

31. See, for example, Ellya's comments in Tempo, 5, 3 (March 22, 1975), p. 46, and the article "Musik Pop dan Lirik Kalut," Tempo, 9, 11 (May 12, 1979), pp. 34-35.

32. Oma very deliberately thought through what experiences and emotions were likely to make some sense to a majority of Indonesian youths. He also became aware that most young people lacked a clear understanding of the complicated Englishand Sanskrit-influenced lyrics frequently used by elite songwriters.

33. The first of these tapes did not appear until 1977. As far as I am aware, Oma was the first to make a practice of printing Indonesian lyrics with his tapes, and a handful of other popular singers and composers have followed suit. Previously, only printed lyrics of English language songs had been included with cassettes. 
it is difficult to establish exactly how much he did know--Oma started to assemble on stage the glamor and glitter that would give his music a visual setting and impact. To the Western eye the result seemed, and still seems, to be so much rippedoff kitsch. There were the long hair, the gaudy open shirts worn with shiny neck ornaments, tight-fitting flared trousers in unlikely colors and trims, and leather boots with stacked heels, all accompanied with as much stage dash as could be mustered. But for the majority of Indonesian youth, rural as well as urban, the flash and kinetic drive were evidently not incongruous; quite the contrary, they were part of a fascinating synthesis with an undeniably Indonesian nature. ${ }^{34}$ The sheer loudness, the heavy beat, the dancing, the words, and the thrilling sensation of being part of a large throng ${ }^{35}$ contributed to and were in turn enhanced by the momentum of the "show." How successful it all was in the public eye can be gauged by the rapid development of a dangdut dance craze that set kampung and village alike to rocking, and by an explosion of dangdut fashions in the wake of Soneta innovations: tiger-print velvet slacks, silver lamé bell-bottomed trousers, calf-length white leather boots with brass heels and toe guards, and ultimately an eye-poppingly romantic, Arabian Nights-like Islamic couture (busana Islam). Audiences everywhere seem to have adored Oma's style, and both well-known and obscure performers imitated it to the best of their abilities. One might legitimately ask how imaginative, not to say bizarre, costuming and dancing with abandon could be related to some of the objectives Oma had set for himself and Soneta Group. There is no easy answer to this question, but a key point surely is that neither Oma nor his audiences viewed the various elements being melded together as anything but complementary . Reality and fantasy carried and strengthened each other, and the impetus they built together moved dangdut beyond music in the narrow sense. Theatrics seemed, in short, to fit the dynamism of dangdut and make of it a comprehensive whole that was somehow larger than its parts. ${ }^{36}$

\section{Dangdut Goes to the Movies}

By 1975 Soneta had found its direction and headed, after a brief dalliance with television, for the medium of film. Considering the close relationship between Ellya's music and films from the very beginning--she had not only been inspired by Indian productions but had starred in numbers of Indonesian-made musicals of this general type from as early as 1956--it is not surprising that the cinema should appeal to Oma. There was also considerable financial logic to the move, for films in Indonesia were becoming bigger business than ever before, showing a capacity to attract large

34. At least, the synthesis seems acceptable and meaningful in nonelite circles. University students have frequently tended to view dangdut as derivative rather than original. See the uncomplimentary remarks in Heri Akhmadi, Mendobrak Belenggu Penindasan Rakyat Indonesia (Bandung?: n.p., 1979), pp. 20 and 173, and Menggugat Pemerintahan Otoriter (Surabaya: Forum Pembelaan Mahasiswa Indonesia, 1979), p. 93. The former publication is available in English as Breaking the Chains of Oppression of the Indonesian People (Ithaca: Cornell Modern Indonesia Project, 1981).

35. Indonesians often seem to enjoy being part of a bustling crowd, and it should be noted that such ramai scenes were deliberately not part of New Order sociopolitical life as they had been of the Sukarno period.

36. It is worth asking whether the music was intrinsically attractive and received only enhancement from the theatrics, or whether the theatrics were necessary to put the music across. Probably the former is true, since dangdut already enjoyed a growing audience. 
audiences. The additional possibility of linking music and movie sales was lost neither on Oma nor the financiers of the highly competitive entertainment business. Soneta, after all, was at least in part a money-making venture that Oma wanted to be not only self-supporting but capable of growth.

At least as important as fiscal considerations, however, were matters related more directly to the creative process. Soneta's music had reached the point at which even the stage show appeared to impose limitations upon it. Technically and physically it was impossible to play live concerts for mass audiences beyond a certain size, and recordings, though they reached a broad public, could not capture the setting or presence that was often such an important part of a number's delivery on stage. Since much of Oma's songwriting was leading inescapably toward both storytelling and moralizing, he was naturally intrigued with the notion of integrating story line more closely with the music, and making of the whole something more "serious."

The first motion picture in what became a remarkable series of dangdut productions was entitled Oma Irama Penasaran (1976) and starred Oma under the direction of A. Haris (b. 1927), who was also responsible for the scenario. Haris was himself a writer of Melayu songs, having authored the classic "Kudaku Lari" while performing with the Orkes Melayu Sinar Medan in the 1950s, and had long experience with films in both Malaysia and Indonesia. He was sympathetic to the basic goal of modernizing a Melayu cinema idiom, insofar as it existed then, and had undoubtedly already given considerable thought as to how such movies might best be constructed for mass audiences. If in retrospect Penasaran seems a forgettable film, quickly overshadowed by its successors, it is still important for the patterns it laid down for future Soneta screen productions. The music was squeezed for every ounce of action available, and a certain amount of titillation as well. The instructions for shooting the opening credits ran in part:

BACKGROUND MUSIC DANGDUT (HOT) ALA INDIA. The camera focuses on the behind of a girl dancing energetically in the [dangdut] style to the rhythm of the music. ${ }^{37}$

The plot borrowed dimly from ludruk and ketoprak, popular urban dramatic forms, and much more directly from Oma's own experiences to put across the intertwined themes of love, personal success, and the defense of proper social and moral values. Here the synopsis is helpful, and is worth quoting at length because to a greater or lesser degree all but one of Oma Irama's films are drawn from it:

[This is] the love story of two young villagers who become fond of each other despite the opposition of the girl's father, a plantation supervisor. The father doesn't want to see his daughter Ani continue to associate with Oma, a young man [he thinks is] a lazy, loafing singer who is not only low class [kampungan] but poor as well. So the father has no compunction whatsoever, when he bumps into the couple on a date, about ordering Oma to leave. Oma takes this as one of the many challenges of life, to be faced calmly and bravely, and also as an incentive to prove he is not the sort of person Ani's father thinks. Only his hidden talent as a singer cannot rise to the surface if he has to stay in the village, where there is neither guidance nor competition. So he leaves the village, taking a necklace given to him by his girl friend as a sign of her true love, and the blessings of his beloved mother, in hopes that he can soon reach his goals. . .

37. This and the following passage are taken from the original movie script, Oma Irama Penasaran, Cerita: Sjam; Scenario dan Sutradara: A. Haris; P. T . Sjam Studio Production, April 1, 1976. 
The struggle in the big city does not go as easily as Oma had expected. He experiences a great deal of bitterness as he comes face to face with all different sorts of people. But the bitterest pill of all is that Oma, in a fight with two troublemakers, is not only hurt but loses his precious necklace to his attackers. He gets help from Susy, a transvestite of the sort the capital city is famous for. It is through Susy also that Oma gets the opportunity to join an orkes Melayu at the Jakarta Fair, where the director of a big recording company sees him and immediately asks him to make a tape. Oma contracts with the company and even appears frequently on television. His tv spots not only attract the attention of Jakartans but ensure that the name Oma Irama is known by the rest of society [masyarakat luas, literally, "society at large"].

By chance Ani sees Oma on television and tells her father, in hopes that he will relent. But the father, who is still very feudal by nature [memang masih tebal sifat feodalisme-nya], refuses to acknowledge his child's feelings. He is just as harsh towards her as before. The result is that an argument ensues between Ani's parents. Her mother is on her side, but can do nothing to help her. So Ani gets fed up and decides to look for Oma in Jakarta. But as it happens they pass each other, for just as Ani leaves, Oma heads back to the village to meet his love. After learning what has happened from Ani's mother, he returns to the city....

[Ani's parents, distraught over her disappearance, go to Jakarta to find her; Oma returns but cannot find her, but one night after a performance he miraculously gets his necklace back.]

The following evening Ani, who has for days waited by the gate of the Jakarta Fair for a glimpse of her loved one, happens to learn from a popsicle seller that Oma is playing on stage just then. She goes in and sees him singing in front of a huge and adoring audience. Oma catches a glimpse of her and, stopping his song in the middle, leaps off the stage and into her arms amidst the surprised crowd. They weep with joy and pent-up longing. . . . Suddenly we hear Ani's parents calling out for their daughter and Oma. As the crowd rejoices, the young people hurry to greet the parents with full emotion and lots of hugging. The father now realizes the way things are; he promises to see to it that Oma and Ani are married forthwith. . . .

The thematic cluster on which this film relies for its social impact and romantic interest was by no means new to Indonesian cinema--village/city contrasts were relatively common fare, and, since 1971 and the enormously successful "Pengantin Remaja," ${ }^{38}$ the love story cutting across status and urban-rural differences had been given a modern setting. But two refinements are worth noting. First, the script goes to great lengths to point out that appearances can be deceiving and that the personal qualities of an individual may have nothing to do with his apparent status in society. Ani's father, whose position as mandor (a foreman or supervisor) would normally entitle him to respect and acceptance as a leader, is presented to us from the beginning as "egotistical, materialistic, and with very little human feeling"; Oma is described as "a village youth of excellent character, patient, respectful of

38. This film, directed by Wim Umboh with a scenario by Syumanjaya, starred Widyawati and Sophan Sophiaan. It won the Asian Film Festival Award in Taipei in 1971 and was widely considered to herald a new age in Indonesian films because of its modern love story (despite heavy influences from Romeo and Juliet and Love Story) as well as its high technical quality. 
elders, and possessed of high aspirations; has a talent for singing." ${ }^{9}$ The audience is consistently asked to look beyond titles and appearances, and admonished not to accept automatically the judgment of others regarding individuals. A case in point is Susy the transvestite, whose plight cannot be entirely ignored or rescued from pity and laughter, but who is clearly shown to share some of the highest values of society. ${ }^{40}$

Second, Penasaran offers not just an abstract moral lesson but a real character and a genuine success story, played out on the screen as it might be played out, we are led to believe, in actual, contemporary life. The innovation of having Oma play himself not only capitalized on a public figure whose name was becoming well known and whose face was being seen in concerts everywhere, but offered instant credibility to the entire scenario. The distinction between fantasy and reality was thereby blurred, an effect accentuated by having a number of other real-life figures in the entertainment world appear playing themselves at different points in the story. "Credibility" was perhaps especially important since the film was meant to tell a cross-class success story in which the underdog wins against all odds . . . at a time when such victories were thought to be particularly difficult. Oma's success, furthermore, was not depicted merely in moral or "traditional" terms--e.g., rural boy loses in city but returns to village, where he is really happy and can rest on his moral laurels--but precisely in the contemporary and material ones of the Jakarta he goes bravely out to conquer. Not only is it possible, the audience is implicitly told, to rise out of nowhere to the top of modern, urban Indonesian society, but there is nothing morally wrong with such an achievement. Judging from the popularity of innumerable variations on this theme among Indonesian audiences--and almost entirely nonelite ones at that-it seems safe to suggest that Oma Irama had struck a highly responsive chord, and one that was more than simply musically inviting.

After Penasaran, Oma Irama and the Soneta Group entered a period of intense activity during which they rapidly developed not simply a more distinctive dangdut style, but what in retrospect must be identified as a new species of dangdut altogether, a broader, more interesting, and more highly focused synthesis of purposes and forms. There were three strong influences at work. The first was Islam, for at this time Oma made the pilgrimage to Mecca and was deeply affected, personally and professionally, by the experience. The name change from Oma to Rhoma, already mentioned, was accompanied by alterations in hair style (shorter, neatly trimmed), costumes (frequently "Moslem", of an especially exotic Middle Eastern type), and message (more didactic). The second influence was politics, for the coming of the 1977 elections offered tempting opportunities to a writer concerned about the message in his songs. Undoubtedly the new public interest in Islam heightened the temptation. It must have been difficult not to conclude that dangdut's proven ability to reach a mass audience could be a powerful political tool. The final change had to do with Western rock music, to which Oma returned in search of ways to enrich dangdut's base without weakening its essential character. In particular, the British group Deep Purple seems to have attracted Oma's ear for its mellow but vibrant bass tones and use of the high-pitched human voice as an instrument. Nothing, however, was borrowed wholesale. The influences as they finally appeared in Oma's songs were remarkably subtle, and they shared attention

39. From the original movie script.

40. This was not precisely new, either, since the same sort of thing appears in ludruk dramas and in a good many silat (loosely, Kung $\mathrm{Fu}$ ) films, which show the good streak in robbers, vagabonds, and the like. 
with other musical changes. For example, at the same time as he was learning from hard rock, Oma was also emphasizing the traditional bamboo flute in ways reminiscent of Sundanese and Minangkabau music.

The result was the appearance within approximately one year, of two films (with soundtrack tapes) and two important cassettes. The motion pictures, Gitar Tua Oma Irama and Rhoma Irama Raja Dangdut (both 1977), followed the pattern of their predecessor but capitalized much more heavily on the Oma Irama character as sympathizer with the underdog (rather than simply being an underdog himself) and as a representative of Good in society. He was given all the trappings of a charismatic figure, fully aware of his popularity and responsibility. In this context it was perhaps natural for a moralizing, didactic strain to show up in the music, and logical as well for this to be heavily colored by Islam. While there was nothing new about mentioning Islam in dangdut--Ellya, for example, had included the line "Let's go to the mosque together and pray" in a late 1950 s number called "Hidup Bahagia"--the practice never developed beyond an occasional mention of prayer or proper behavior, or a very casual effort at moralizing. Oma, however, moved boldly into the arena of what can be designated as dakwah music, that is, music with a conscious Islamic message. He went so far as to include Koranic phrases in his compositions, an innovation as surprising to Moslems who considered themselves devout as to those who did not. Thus we get, from Gitar Tua, a description of the Day of Judgment in the song Kiamat, and from Raja Dangdut the musically impressive and exceptionally popular "Laillah Haillalah":

Bismillah hirohmanirohhim kulhu allah hu ahad allah hu somad

lam yahid walam yulad walam yakkul lahu kufuan ahad. ${ }^{41}$

Say that God is One

God, the object of our prayers and supplications

Say that God is One

God, who has no children and is the child of none

Laillah haillalah, there is no God but Allah

Laillah haillalah, there is no God but Allah

Why do you worship human beings, why do you worship material things

You shouldn't think there can be two of Him

You shouldn't think He shares his holiness with others ${ }^{42}$

He created all of nature and there is nothing else like Him

Laillah haillalah, there is no other God but Allah

Laillah haillalah, there is no other God but Allah

Bismillah hirohmanirohhim kulhu allah hu ahad allah hu somad

lam yahid walam yulad walam yakkul lahu kufuan ahad

Katakan Tuhan itu satu

Tuhan tempat menyembah dan tempat meminta

41. The lines comprise the last verse of the surah Al-Ikhlas. As Oma later pointed out to critics, he did not sing these lines, but spoke them as an introduction to the song. He, therefore, did not compromise the integrity of the Koranic text. It should be pointed out, however, that the lyrics of the song are in fact a loose translation of this verse.

42. Here the meaning is, of course, that Allah has no "allies" or "partners" in the way that the Christian God can be thought to comprise a Trinity. Allah is unique and alone. 
Katakan Tuhan itu satu

Tuhan tidak beranak dan tak diperanakkan

Laillah haillalah, tiada Tuhan selain Allah

Laillah haillalah, tiada Tuhan selain Allah

Mengapa kau Tuhankan manusia, mengapa kau menuhankan benda

Janganlah kau menduakan Dia, janganlah kau menyekutukanNya

Alam dan isinya semua ciptaaNya, tiada satupun yang manyerupaiNya

Laillah haillalah, tiada Tuhan selain Allah

Laillah haillalah, tiada Tuhan selain Allah ${ }^{43}$

It is worth noting that this number, with its exceptionally strong downbeat and rich coloration, became a favorite dance tune.

The collection of songs produced on cassette tapes (and not included in the films) struck out on a rather different course. Several of these tunes, written with the circumstances of election campaigns and issues in mind, treated contemporary and often controversial subject matters with simplicity and openness. The song "Hak Azasi," for example, expressed a clear opinion about the meaning of basic human rights and catalogued them straightforwardly. ${ }^{44}$ The celebrated tape Rupiah is another example, the title song of which commented acidly on the scramble for money Oma saw around him. The words ran in part:

Even when they have to

Risk their very lives to do it Lots of people take the gamble

Just to get their hands on the Rupiah.
Walaupun harus nyawa Sebagai taruhannya Banyak orang yang rela Cuma karena Rupiah ${ }^{45}$

43. Rhoma Irama Raja Dangdut, Soundtrack from film (Cassette, Naviri, 1977-78) .

44. Hak Azasi (Cassette, Yukawi, 1977-78). The first lines ran:

Respect basic human rights

That's the duty of all mankind

We are all free to choose

How we wish to live

Even God doesn't force

His subjects to behave in a certain way

Freedom of religion,

That's a basic human right

Freedom of speech

That's a basic human right

We are free to do as we wish

As long as we don't conflict

With Pancasila
Hormati hak azasi manusia Karena itu fitrah manusia Kita semua bebas memilih Jalan hidup yang disukai Tuhanpun tidak memaksakan Apa yang hambaNya lakukan

- .

Kebebasan beragama

Itu hak azasi

Kebebasan berbicara

Itu hak azasi

Kita bebas untuk

Melakukan segala-galanya

Asal saja tidak bertentangan dengan Pancasila

45. Rupiah (Cassette, Yukawi, 1977-78). This song was preceded by a far less interesting composition called, simply, "Uang," which probably dates from about 1975. See Uang: Oma Irama Melayu Dangdut (Cassette, Rolex-Irama Tua, 1976-77?). It is possible that Oma was here influenced by Pink Floyd's "Money," which appeared in 1972-73, but if so only the general subject matter was carried over into his work. Compare the Pink Floyd lyrics, which run in part: "Money, get away, get a good job, with more pay, and you're okay / Money, get back, I'm all right Jack, keep your hands off my sack / Money it's a hit. . . ." 
The song was prohibited from being played on television, and according to many cassette salespeople the tape itself was forced off the shelves in an indirect manner, but ultimately because of government threats. By Oma's own account, a government representative told him the lyrics were unacceptable because they "debased the national currency," to which he replied that his intent was not to criticize the monetary unit, but the people who misused it.

Three new motion pictures, with accompanying sound-track tapes, appeared in 1978. They not only confirmed Oma Irama as the "King of Dangdut" but made him the giant of the Indonesian movie industry and the most widely recognized figure in the archipelago. In these films the various themes and approaches already experimented with were brought together. Both Begadang and Berkelana (which was presented to the public in two installments) returned to the style of Penasaran in that they retold a fictionalized Oma Irama biography, but they retained the musical advances made since that time, especially the expansive, highly electrified sounds and the mixing of dangdut and rock beats. In addition, religion became an important element in the enterprise, mixing with romance and social commentary in a generally didactic and "uplifting" story.

It was Begadang which introduced what became the most popular tune of 1978 , sung and danced in kampung and villages everywhere:

What good is Saturday night

To people who aren't well off

We want to have fun but got no money

End up squatting at the side of the road

. . .

Those who have money

Go dancing at nightclubs

We who have no money

Just dance at the side of the street

Those who have money

Eat in big restaurants

We who have no money

Eat only at roadside stalls
Apa artinya malam minggu

Bagi orang yang tidak mampu

Mau kepesta tak beruang

Akhirnya nongkrong di pinggir jalan . . .

Bagi mereka yang punya uang

Berdansa-dansi di night club

Bagi kita yang tidak punya uang

Cukup berjoget disini

Bagi mereka yang punya uang

Makan-makan di restoran

Bagi kita yang tak punya uang

Makannya di warung kopi. ${ }^{46}$

The social bite of this song, not dulled by its easy singability and danceability, was evident also in Berkelana ll's "Termenung":

Why are people not the same?

Why are the poor and rich so different?

Why does love have limits set

That say rich and poor cannot be lovers?

Mengapa manusia tiada sama

Yang miskin yang kaya ber-beda-beda

Mengapa bercinta ada batasnya

Yang miskin tak boleh dengan yang kaya ${ }^{47}$

Close on the heels of these social reflections came several songs more in the dakwah vein, less explicitly critical and more inspirational in nature. The numbers were clearly designed both to enhance the Oma character as a representative of justice and to emphasize the validity of Moslem values in everyday life. In the song

46. Begadang (Cassette, Yukawi, 1978).

47. Berkelana //, Soundtrack (Cassette, Naviri, 1978). 
"Perjuangan dan Do'a" from Berkelana // the secular and religious struggles are brought together:

First you pole the raft upstream

Then you swim to shore,

First it hurts, at first it's hard

But then you reach a happy goal

Bitter is the taste of gall

But sugar's taste is sweet

Work hard first, struggle first

Then you will find happiness

Struggle, struggle with all your might

But don't forget to accompany it with prayer

There will always be obstacles in the way

Just confront them patiently and magnanimously

Berakit-rakit kehulu, berenang ketepian

Sakit-sakit dahulu, susah-susah dahulu

Baru kemudian bersenang-senang

Pahit rasanya empedu, manis rasanya gula

Bekerjalah dahulu, berjuanglah dahulu

Baru kemudian berbahagia

Berjuang, berjuang sekuat tenaga

Tetapi jangan lupa perjuangan harus pula disertai doa

Rintangan, rintangan sudah pasti ada

Hadapilah semua dengan tabah juga dengan kebesaran jiwa ${ }^{48}$

Those who are well acquainted with Oma indicate that his goal is to create a music both modern and indisputably Indonesian, meaningful and appealing to "the masses" beyond the urban elite. That he has tried to express his religious concerns in his lyrics may well reflect a happy convergence of personal conviction and the culture of his audience.

In 1980, the most ambitious of the Oma Irama films appeared, the astounding Perjuangan dan Do'a, which almost certainly qualifies as the world's first Islamic rock (and, needless to say, dangdut) musical motion picture. ${ }^{49}$ Lacking an even moderately intricate plot, the film does little else but provide an enhanced visual setting for the music and its heavily dakwah message. But what a setting! Using the simple device of interspersing story segments shot in natural surroundings with illustrative musical numbers shot directly as wildly fanciful stage productions (from actual concerts), Oma juxtaposes reality and fantasy in an artificial but internally consistent and convincing manner. The audience is thrown from an environment of ordinary roadside food stalls and unaffected kampung interiors to scenes in which, for example, Oma and the Soneta Group, swathed in glittering silverish robes and turbans, playing from the eye sockets of a giant green skull lit with flashing red and white laser beams, grind out a rousing dakwah number about the perils of thinking ill of others. Horrific on paper, perhaps, the whole thing works very well on screen; the effect is to give the production a larger-than-life quality, and to underscore the dakwah message--drive it home--with an especially intense energy.

48. Berkelana $/ 1$.

49. I have not been able to consult the original script for this production. Comments below are based on my viewing of the film in August 1980 and August 1982 . Perjuangan dan Do'a, Cerita: Rhoma Irama; Sutradara: Maman Firmansjah; Rhoma Irama Productions, August 1980. 


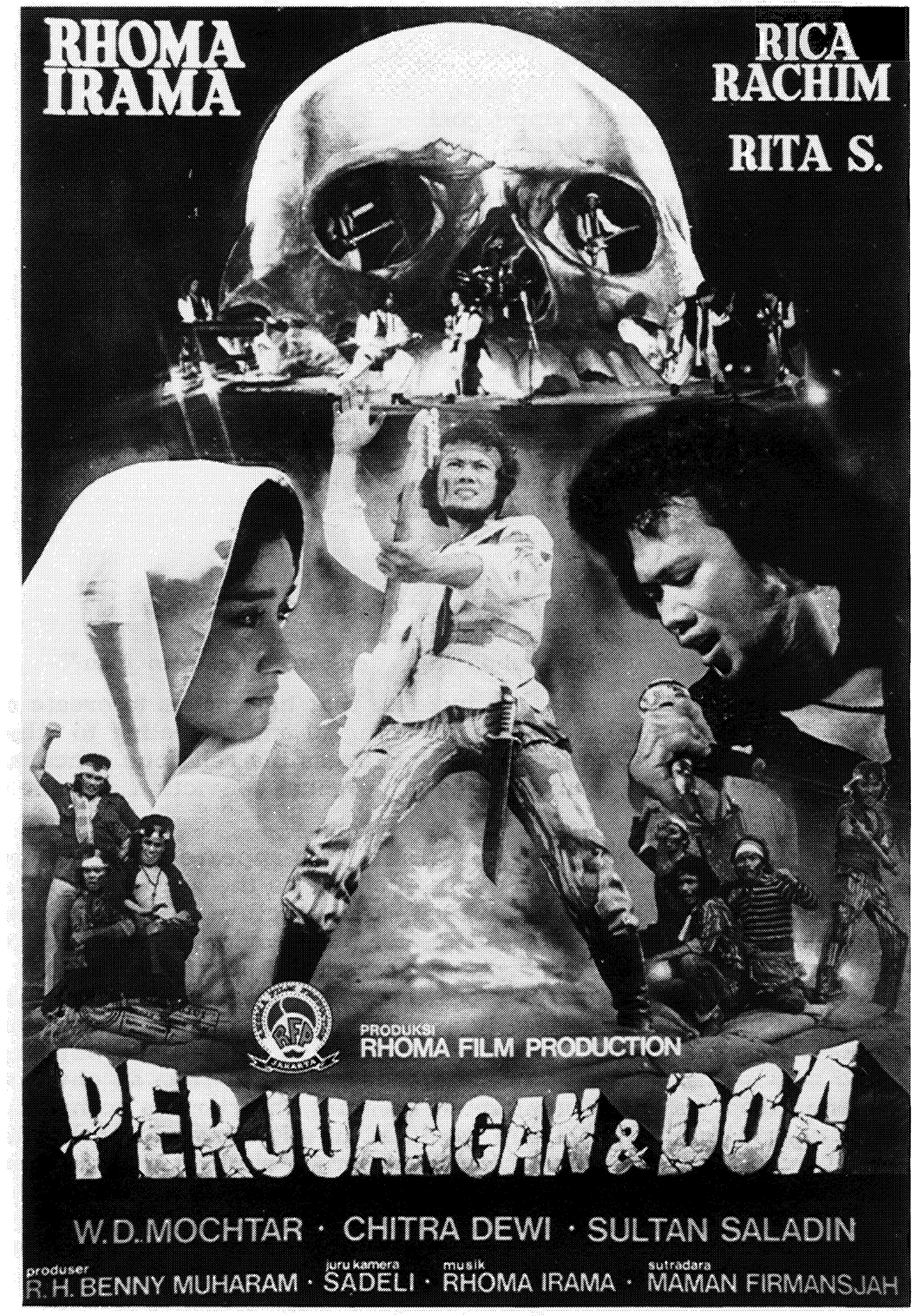


While it is perhaps enough to appreciate Periuangan dan Do'a as a creative exercise in the music-film medium, the variety of messages it seeks to get across are also important. There is, first of all, a warning not to have a pretentious bearing where religion is concerned (jangan sok suci) and to understand the basics of Islam in a straightforward manner. The song "Haram"--eminently danceable and offered in the film as part of a mass joget scene--is probably the best example in contemporary Indonesian music of an elementary piece of dakwah in a "pop" setting:

Why oh why is alcohol forbidden

Because oh because it destroys the mind

Why oh why is adultery forbidden

Because oh because only animals do that

Why oh why is everything pleasurable forbidden

Why is everything that's fun prohibited . . .

$A h$, ah, ah that's the trap the Devil sets

With all kinds of tempting baits, hey, hey, hey

Kenapa e kenapa minuman itu haram

Karena e karena merusak pikiran

Kenapa e kenapa berzinah juga haram

Karena e karena itu cara binatang

Kenapa e kenapa semua yang asyik-asyik itu diharamkan

Kenapa semua yang enak-enak itu dilarang. . .

$A h$, ah, ah itulah perangkap setan

Umpannya bermacam-macam kesenangan, hei hei hei ${ }^{50}$

There is much more complexity and interest, however, in dakwah poured into the crucible of social criticism, and Oma has learned to accomplish this with great skill. There is no better example in his entire repertoire than the number "Nafsu Serakah," the music of which not only forges an entirely new acid-rock dangdut but offers an exceptionally powerful vehicle for the words:

All over this part of the world

We hear the drumbeats answering each other.

All over this part of the world

So many dead lie scattered everywhere.

It's all the result of insatiable greed.

People who lust, in their cunning, for power

Will do anything and think it's all right.

Have we now returned to the law of the jungle

With the strong oppressing the weak?

A small group of power-hungry people

Fill the world with suffering.

Stop aggression, stop tyranny,

When will we ever see justice done?

Almost everywhere in the world

We hear the cries of a restless humankind.

Almost everywhere in the world

Human beings are falling prey to their own kind.

The reason is that man has forgotten his Creator

And turned religion into little more than an addendum.

Men have begun to worship material things

50. Perjuangan dan Do'a, Soundtrack (Cassette, Yukawi, 1980). 
Dimana-mana di belahan muka bumi ini

Terdengar suara genderang silih berganti

Dimana-mana di belahan muka bumi ini

Teramat banyaknya bergelimpang manusia mati

Itu karena nafsu serakah

Manusia yang ingin berkuasa dengan segala kelicikannya

Berlakulah halal segala cara

Apakah sekarang berlaku lagi hukum rimba

Golongan yang kuat menindas golongan yang lemah

Segelintir orang yang haus akan kekuasaan

Membuah dunia penuh penderitaan

Hentikanlah penindasan, hentikan kezaliman

Kapan kiranya akan tegak keadilan

Dimana-mana hampir di seluruh punggung dunia

Terdengar suara keluhan manusia yang gelisah

Dimana-mana hampir di seluruh punggung dunia

Banyak manusia jadi mangsa dari sesamanya

Itu karena sang manusia sudah lupa kepada Penciptanya

A gama hanya pelengkap belaka

Manusia telah bertuhan dunia ${ }^{51}$

These verses and their companions brought dakwah dangdut to a state of maturity, giving it a permanent place in Indonesian pop music. ${ }^{52}$

Two less obvious aspects of the cinema production, not readily accessible through lyrics and delivery, differentiate Periuangan dan Do'a from Oma's earlier films. First, although the narrative portion of the film centers (as usual) on Oma, this is in a fashion quite different from before. As usual Oma plays the moral hero, battling alcoholism, incest, and the like; but he is also depicted as defending himself against detractors and standing fast on a highly personal vision of proper Islamic thinking and behavior. One of the principal problems posed and then "solved" in the film, for example, is whether dangdut is really a proper medium for proselytization; Oma battles the charge of impropriety in a public debate overseen by a respected kiyayi.

The second new element in Perjuangan dan $D o^{\prime} a$, although never fully developed, lies in its expression of nationalism. In the film Oma tries to relate his proselytizing and social criticism to the core of the Indonesian "national experience": the revolution. In the number "Nafsu Serakah," precisely at the line "Have we now returned to the law of the jungle?" the Soneta Group players are suddenly flashed on screen as young fighters in the Indonesian revolution of 1945-49, complete with red-andwhite headbands and bombs bursting in air.

Periuangan dan Do'a is exemplary of the Islamic pop culture that Oma is concerned to disseminate. ${ }^{53}$ In this and his other recent work, Oma appears committed,

51. Periuangan dan Do'a.

52. While some of the love songs and lighter compositions have enjoyed intense popular attention, the dakwah music seems so far to have had greater lasting power. Oma's dakwah tunes have not, furthermore, attracted rivals in different styles; when people think of contemporary dakwah music they seem to think virtually exclusively of the sort that Soneta Group plays.

53. It should be added that, since making this film, Oma has experimented with different projects. The first of these was a romantic musical called Melodi Cinta Rhoma Irama (1981) that offered an exact replica of secular (and frequently Christian) upper-middle-class productions except that it was molded by an Islamic world 
in a fashion not discernible in the work of any other popular artist or filmmaker, to communicating clearly definable messages to the broad public. Is this the--or at least a--secret of his phenomenal success? It is not impossible, and many of Oma's contemporaries believe that his search for relevance has driven him to understand the concerns and outlooks of nonelite Indonesians more thoroughly than others. Whatever the case, the whole matter of why and how Oma Irama's dangdut has been popular lies at the core of any analysis of his style and of its impact on popular culture as a whole.

\section{Dangdut Fever: Reaction and Response}

Dangdut fever has not been an imaginary disease in Indonesia. On Saturday evenings near Jakarta's National Monument, thousands of youths gather at an entertainment center to listen as dangdut bands pump out their special sounds and to dance far into the night. Some singers wear spangled outfits and carry the latest electronic gear, while others get by more modestly with blue jeans and second-hand instruments; the crowd, too, ranges from the expensive, sheen-shirted types to kampung kids in rubber thong sandals or bare feet. Similar scenes are recreated in countless lesser cities and towns, and in villages as well. By day, dangdut cassettes bring the distinctive beat to curbside eating stalls and kampung windowsills, as well as to the fashion shows and hotel receptions of the Jakarta rich. As is generally true with pop culture phenomena, this "fad" also happens to be big business. Even roughly accurate figures are exceptionally difficult to come by, but it seems likely that of the seven to eight million cassette tapes produced monthly in Indonesia during 1980-81, about half were devoted to dangdut. ${ }^{54}$ Tapes by superstars like Oma Irama and, to a somewhat lesser extent, Elvy Sukaesih, A. Rafiq, and others, sell millions of copies each year; some of Oma's songs, which have proven to be the most durable, have sold at a reasonably steady rate for several years and have been widely pirated. Dangdut movies seem to have ruled the cinemarket between 1977 and 1981, though the way in which attendance is presently measured makes this hard to prove. The biggest box-office smashes attract in the neighborhood of four to five million paying customers each; Oma Irama films may have been seen by as many as fifteen million Indonesians--one-tenth of the population--in the years 1978-79 alone. ${ }^{55}$ It is understandable, then, that the biggest dangdut stars

view. The film was not successful in expressing social criticism of the kind the public had come to expect from Soneta and was unenthusiastically received. His current project is for a film based on the life of the nineteenth-century Minangkabau hero, Tuanku Imam Bonjol (with Oma in the title role), that would offer an Islamic alternative to the recent crop of successful historical films, which have placed little emphasis on religion.

54. It is unfortunately difficult to be more precise, as official records (made at least partly for tax purposes) are generally conceded to be misleading, and the large tape-pirating industry in Indonesia is, of course, beyond all but the roughest statistical grasp. I am basing these numbers on the general figure of six million cassettes per month reported in 1979, and on information passed on to me confidentially in conversations with leading Jakarta recording producers in August 1980 .

55. Here again data is a problem, largely because records of movie attendance at middle- and low-class movie theaters, especially those outside cities and major towns, are inaccurate or nonexistent. Officially, the most popular films have attracted audiences of four to five hundred thousand in recent years, and the dangdut films almost never figure in lists of hits. (Nor are they entered in the annual film festival competitions.) But producers of all genres of film seem to agree in private that 
have received two, three, and even four times the fees per motion picture normally commanded by matinee idols like (in 1978-79) Roy Marten and Yati Octavia. The profits involved have forced virtually every major musical entertainer in Indonesia to produce material in the dangdut style. Firm devotees of rock, such as Achmad Albar, or of Western pop, such as Titi Qadarsih, were inexorably, if temporarily, caught up in the trend. 56

The evidence, however imprecise, gives the strong impression that dangdut is not only vastly popular, but that it is so in a way quite unlike any other modern cultural form in Indonesia; to put it plainly, it seems to correspond to popular taste at its broadest. Respected composers like Mus Mualim have commented that dangdut "is what the people want," and leading publications such as Tempo have asked rhetorically, "Who knows, maybe the Melayu rhythm really is the one that best fits Indonesians after all." 57 There is general concurrence, as well, that dangdut's popularity is intimately connected to its egalitarian character. In the eyes of many observers, the music not only gets the majority of its fans from the majority of society--the lower classes--but evinces a sympathy with and understanding of them that is unique. Indeed, this last characteristic has been strong enough to breed a kind of "populist chic" (kegenitan sosial) among the elite and middle class. ${ }^{58}$ For these reasons some have concluded that the dangdut style, by virtue of what it reflects as well as what it imposes, matches more accurately than any other yet devised the much sought-after national character or "countenance" (wajah Indonesia). 59

Yet a good deal of controversy has arisen over dangdut's popularity. Minister of Education Daud Jusuf has on numerous occasions declared that the music is nothing more than caterwauling. Another angry commentator has said that dangdut is "dog crap music." 60 Part of the hostility undoubtedly derives from the offhand perception that the dancing and theatrics spell an assault on "conventional" values, much as Elvis Presley's pelvic gyrations were considered to subvert American morality in the 1950s. More thoughtful, if equally hostile, detractors have pointed to the commercial aspect of dangdut fever, arguing that the root cause of the "sickness" is a dangerous combination of big money and mass-media technology. Because the dangdut craze coincides with the first time in Indonesian history that mass advertising, via television, cinema, and radio, to say nothing of print, has reached a truly large and heterogeneous audience, there is a tendency for observers to blame

the real situation is very different and that the rough numbers given here are probably close to the truth. The fifteen million figure for Oma's 1978-79 films (five or six were in circulation) is conservative and counts only people who have seen one or more films, not number of tickets sold. The figures may seem high, but Oma is said to have commanded Rp. $12,000,000$ per film in 1979 , and offers at this level would not be made if the return were not commensurate.

56. See, for example, Achmad Albar's Zakia (Cassette, Sky Records, 1979) and its cover photograph of Arabian Nights getups of the Afro-coifed (kribo) renegade from rock.

57. Quotes from Tempo, 5, 3 (March 22, 1975), pp. 49 and 2 respectively.

58. Mira Sato, "Dangdut: Jangan Jadi Candu," Kompas, September 10, 1979.

59. See, for example, Eddy Iskandar, "Benarkah Film Dangdut Wajah Film Indonesia?" Pikiran Rakyat, November 10, 1979; and "Sulit Mencari Film Nasional yang Betul $^{2}$ Berwajah Indonesia," Suarya Karya Minggu, March 23, 1980.

60. Quoted in Remy Sylado, "Music Pop Makin Ndeso," Dialog, 33 (February 4-17, $1980)$, p. 64 . 
the "big bosses" (tauke) of media enterprises for deliberately creating a taste and market, rather than simply reacting to currents already flowing. ${ }^{61}$ The implication is that the bulk of the population has been hoodwinked into debasing their natural good taste and becoming infatuated with a bogus and shallow cultural form.

A related argument found in much public consideration of dangdut has to do with whether or not the music reflects anything of intrinsic value. One detects more than a hint of disillusionment with "the people's" taste in jazz musician Jack Lesmana's remark, "Why give [the people] beef steak if what they really hanker after is gado-gado [an inexpensive vegetable salad] ?" 62 While there is broad acknowledgment that dangdut is essentially kampungan in nature, the precise meaning assigned to that expression is unclear. For a few it simply means "bad"; for a much larger group of elite and would-be elite, the sense of "substandard" or "low quality" probably suffices; others may be, genuinely or otherwise, more sympathetic but still convey a judgment of vague inferiority or poor taste when they use the term; and for a few the word is uttered with a defiant sort of pride rather akin to Oma's when he accepted the designation "dangdut" for his kind of music. ${ }^{63}$ On the one hand, nearly every aspect of dangdut has been attacked: the simplistic lyrics, the Islamic content, the often blatant but "laundered" sensuality, the "crazy vitality" and "phony dynamism," and even the pseudo-autobiographical content of the films, which one enterprising critic portrayed as a kind of masturbation. ${ }^{64}$ On the other hand, Elvy Sukaesih's contention that "the people [masyarakat, society as a whole] are good judges, they can evaluate an artist perfectly . . . and justly" 65 typifies the point of view that, although kampungan or mass culture is different from the "higher" arts, it is not without standards and a thoughtful public of its own.

What had crystallized out of this swirl of opinions by the late 1970s was a polemic in which the kampungan forces were opposed by those dubbed gedongan, from the root gedung, or urban, concrete, multistory building. ${ }^{66}$ It became necessary to identify one's musical style or preference in terms of one or another of these stereotypes, and for a time university campuses were rent by this faddish dispute. ${ }^{67}$ The foremost exponent of the gedongan style has been Guruh Soekarno (b. 1953),

61. Lambasting "crass commercialism" as a principal illness in contemporary Indonesian society has become a standard activity for intellectual writers in analyzing "what's wrong with popular culture." For good examples, see the Prisma issue cited above (note 5 ).

62. Tempo, 5, 3 (March 22, 1975), p. 49.

63. A recent dictionary of synonyms yields, for "kampungan," the equivalents "embarrassing" (memalukan), "worthless" (tak berharga), and "bad" or "awful" (buruk, jelek). Harimurti Kridalaksana, Kamus Sinonim Bahasa Indonesia (Ende: Nusa Indah, 1977), p. 60. The pride in being kampungan these days is much like the pride native Surabayans often take in being kasar, or coarse and crude, as opposed to the Central Javanese and elitist halus, or smooth and refined.

64. "Dangdut versus Remaja," Minggu Merdeka, February 3, 1980.

65. Quoted in Sinar Harapan Minggu, December 9, 1979.

66. The intent, naturally, is to express in a word similar but opposite to the succinct and rather eloquent "kampungan" the notion of "good" and "high class." "Gedongan" is not an entirely new coinage (neither is "kampungan"), but in this particular usage--which began as a kampung put-down and was adopted, like "kampungan," with a sly pride--is recent.

67. Based on my own experience in Yogyakarta during 1978. 
son of the first president of Indonesia and a musician since his early teens. Long a student of classical Javanese and Sundanese music while, at the same time, intimate with Western jazz and classics, Guruh set out in 1974 to elevate existing IndonesianWestern pop music and create a kind of neoclassic, syncratic style that would be at once Indonesian and international. But even those who looked at Guruh's more serious compositions as being of some quality acknowledged that his music in general was "not capable of speaking to society at large . . . it is foreign to most people's ears." 68 The rise of dangdut sharpened composers' sensitivities to this aspect of popular music, with the result that from the mid-1970s there flourished a wide selection of semi- or non-dangdut approaches to producing an equally powerful "pop" music, that is, one both popular and populist.

A few of these efforts are worth describing briefly because they illustrate the wide range of creative effort that dangdut has been at least partially responsible for eliciting from contemporary Indonesian society. One attempt has been to infuse a Guruh-like synthesis (primarily of gamelan and Western pop) with a kampungan character, and attempting in this way to make the point that kampungan is, in fact, not merely okay but in some respects and circumstances a positive good. Thus a Yogyakarta group close to W. S. Rendra formed a music-theater ensemble known as Kelompok Kampungan. Their tape Mencari Tuhan seeks to be spontaneous, reflective of things the way they really are in the world, and patriotic (excerpts of Sukarno's speeches from the 1960s are played to introduce musical numbers). ${ }^{69}$ They have tried to "make music with a kampung spirit" and to anticipate what is (or, perhaps, should be) in the minds of kampung folk:

They're searching for God

They're getting close to Nature

They're getting into Life

They're beginning to distrust

The old, established values. . .
Mereka mencari Tuhan

Mereka mendekati alam

Mereka mendekati hidup

Mereka mulai meragukan

Nilai-nilai yang sudah mapan . . .

Yet the effort seems forced and abstract; however well intended it does not have that ring of social truth about it; these are university students and artists playacting the roles of "ordinary people."

A simpler, less pretentious and self-conscious handling of the populist theme from a more-or-less upper-class position is seen in the compositions of Leo Kristi (b. 1948). He has adopted a spare American "country" style, and since 1975 has marketed it under the name of his small group, Konser Rakyat. True to his arèk Surabaya origins, Leo has made a point of avoiding glamor and romanticism in his work, and has noted frankly that, while his music obviously does not issue straight from the masses (rakyat), it sometimes attempts to take the rakyat point of view. 70 His songs are thus intended as much to educate elite listeners as to entertain the masses. Generally lyrical and optimistic, the Konser Rakyat songs can occasionally be barbed, as in the well-known "Dibawah Monumen Sudirman," which symbolically depicts Indonesia's poor, huddled sorrowful and forgotten at the feet of a cold military. ${ }^{71}$ And the tune "Salam dari Desa" has its own bittersweet flavor:

68. Titiek Puspa quoted in Topik, 22 (November 23, 1978), pp. 6 and 7 .

69. Cassette, Akurama, 1980. The quotes below are taken from the accompanying printed material. For an appreciation of the group as having provided a service in making dangdut more acceptable, see Waspada, August 29, 1980.

70. Subangun/Maruli, "Musik Rakyat Leo Kristi," Kompas, August 22 and 23, 1980; Kistanto, "Leo Kristi Troubadour Indonesia Masakini," Kompas, August 16, 1978.

71. Nyanyian Malam (Cassette, Irama Tara, 1977-78). 
Tomorrow when you go to the city

Send my fond regards [to people there]

Tell them the sugar cane's in bloom

A vast field of white

Day and night the trucks go by

Their wheels are turning, turning

But they don't belong to us

Kalau ke kota esok pagi

sampaikan salam rinduku

katakan padanya

tebu-tebu telah kembang

putih-putih seluas padang

road lori berputar-putar

siang malam

tapi bukan kami punya ${ }^{72}$

Works of this type are exceedingly well received on university campuses, where audiences seem to find both a gedongan quality (a refinedness and an international flavor) and a thoughtful populism in the music. ${ }^{73}$ It is Leo Kristi whom most guitarplaying students imitate, and it was the music of Konser Rakyat that provided the model for Ebiet $G$. Ade, who created a brief sensation in 1980-81, but could not recreate the genuinely earthy, honest quality of Leo Kristi's work.

Less intellectual and more romantic is the music recorded over the past four or five years by the duo known as Franky and Jane (Sahilatua). Popular far beyond educated circles and the groups reached by Konser Rakyat, this "country-folk" group has, since its first recording in 1978, turned increasingly toward "village songs" and lyrics that contrast village and city lives. It is light and sentimental stuff, but not without point. Working with the young writer Yudhistira Ardi Nugraha, Franky and Jane have produced a stream of tunes with straightforward, unaffected lyrics that treat unlikely subjects such as riding city buses. A particularly good example, which succeeds both as unpretentious music and effective idea, is Franky's song "Supermarket dan Petani":

A farmer climbs on a bus

Gets off in the center of the city

Outside a supermarket he looks inside

At the fruits and vegetables all neatly tied in bunches

He shrugs his shoulders in amazement

So much food in cans

Everything in the supermarket

Has become so foreign to him

City people only know

How to buy things

They've forgotten about the villagers

Patiently waiting

From season to season

For the fields to yield

Seorang petani naik bis kota

Ia turun ditengah kota

72. Nyanyian Tanah Merdeka (Cassette, Irama Tara, 1979).

73. Personal observation of a Leo Kristi concert in Jakarta, August 1980, and discussion with students in the audience. 
Melihat dari luar supermarket

Sayur buah yang dibungkus dengan rapi

Ia mengangkat bahu keheranan

Banyak makanan dalam kaleng

Semua yang didalam supermarket

Menjadi asing baginya

Orang kota hanya tahu

Bagaimana membeli

Lupa akan petani di desa

Yang penuh kesabaran

Menunggu tanah kebunnya

Dari musim ke musim ${ }^{74}$

The populist spirit has, it is important to note, colored creative activities in contemporary Indonesia well beyond pop music, and for this reason the "extended dangdut style" deserves to be more broadly recognized.

\section{Conclusion: Dangdut and the State of Society}

What does all this reveal about Indonesia today? We can settle most confidently on three principal conclusions.

First, it indicates that the 1970s have been years of great cultural vitality, particularly in the area of popular, mass-media-dominated culture. Though many foreigners and Indonesian intellectuals have been inclined to dismiss this pop culture as derivative, neocolonial, and comprador, such a judgment overlooks the obvious dynamism of the phenomenon. While one could argue that it is difficult not to find artistic vitality in Indonesia in almost any period, the rise of the dangdut style could not have taken place--let alone had the same impact--in the Sukarno era. The commercial drive and resulting competition were not there; the media technology (on the receiving as well as the sending end) did not exist; the Islamic content, to say nothing of the Western influences and the dancing, could not have survived in the ideological climate of Guided Democracy; and the personality cult of media stardom as well as the individualist message would not have been tolerated by officialdom. There is clearly something about the dangdut style, neither ideological nor entirely natural, that belongs to its time and circumstance.

Second, this pop-cultural phenomenon illuminates in ways that other sources, especially quantitative ones, cannot, the nature of the enormous changes Indonesia has undergone in the past decade. If there is a typical dangdut "social tale," it is that of the poor-boy-makes-good, rags-to-riches sort. Whether or not there have in fact been many such overnight successes, the society-wide impression seems to be that transformations of this kind have been taking place, and that the social barriers of the past are everywhere being questioned and broken through. The Inem Pelayan Sexy films by Nya Abas Acub (b. 1932), in which a servant-girl leaps by chance and a certain cleverness to the top of more-or-less polite, modern, urban society mirrored this sense of flux in a manner that was instantly understood throughout Indonesia. ${ }^{75}$ It is no insult to suggest that the spirit of these films places them squarely within the generous bounds of the dangdut style. Yet if old barriers have been broken through, the 1970s have also witnessed a seemingly

74. Panen Telah Datang (Cassette, Jackson Records, 1979). See the review in Berita Buana, January 23, 1980.

75. There were three films in the series, the first of which was in its day the most popular Indonesian film, judged by official attendance records. 
ever-widening gap between rich and poor, powerful and powerless, gedongan and kampungan. Awareness of this gap, and sensitivity to the condition of the lower classes have been central to dangdut and the myriad genres it has influenced. This awareness has evidently made a certain political impression at both ends of the social scale. It is not surprising that in the 1982 election campaign, both Golkar and the PPP utilized top dangdut stars to attract large crowds, with Oma appearing for the latter, and a battery of other singers, including Elvy Sukaesih, for the government party. ${ }^{76}$ To be sure, Oma has steadfastly maintained that his "field is music, not politics, ${ }^{77}$ and that he will remain a musician not a political leader, yet he has become a figure with much more political significance than a simple entertainer. Publicly urging his fans--and all good Moslems--to vote for the PPP, Oma also spoke on national television to decry the gap between rich and poor in Indonesia, and to argue that the Moslem party offers the best means for closing it. ${ }^{78}$ He has taken well-defined public stands on related sensitive social issues, and with his dangdut style has done much to keep the subject of social inequities central to popular cultural life.

Finally, the development of dangdut suggests some interesting trends in Indonesian Islam. From other evidence it is clear that since 1975 or so there has been a growing "Moslem revival." But dangdut indicates that this movement is by no means merely fundamentalist or exclusively lower class in nature. Dakwah music--and not only of the dangdut variety ${ }^{79}$--has turned out to be big commercial business. ${ }^{80} \mathrm{~A}$ certain vogue has even developed for "Islamic boutique" fashions and for making the pilgrimage to Mecca (as a parade of pop stars has done since 1977) ${ }^{81}$--something very difficult to imagine earlier in Indonesian history. At the same time, a Moslemstyle social-critical element is quite clear in dangdut, as well as a strong emphasis on individual and public morality.

The complexity of the ties between Islam and dangdut suggest that there is probably a greater degree of flexibility and change in the religious thinking of contemporary Indonesia than has thus far been appreciated. In the same year Oma Irama sat down to think out the premises on which dangdut might be built, another individual rocked the Islamic community in a more bookish but not entirely dissimilar way. Nurcholish Madjid's speech calling for secularism without secularization, a kind of desacralization of Islamic life in Indonesia, began an emotional debate. ${ }^{82}$ However much it revealed about fissures in the Moslem community, the polemic was

76. Tempo, 12, 4 (March 27, 1982), pp. 12-15.

77. Tempo, 11, 4 (March 27, 1981), p. 22.

78. Berita Buana, April 13, 1982; Merdeka, March 13, 1982; on Oma's official statement of endorsement, see Pelita, March 15, 1982.

79. On a composer who attempted to use Western light classical music as a dakwah medium in the 1970s, see Yusuf Abdullah Puar, Periuangan A. Mukhlis, Komponis Musikus Dakwah (Jakarta: Pustaka Antara, 1978).

80. Oma Irama's special dakwah tapes, made by his producers for an audience they rather suddenly discovered, are exceedingly popular and frequently pirated. Two examples are Keramat: Top Hits Dakwah Soneta (Cassette, Yukawi, 1979?) and Syillu Shout (Cassette, Yukawi, 1978-79).

81. See, for example, Tempo, 8, 52 (February 24, 1979), p. 13.

82. The basic statement is contained in Nurcholish Madjid and others, Pembaharuan Pemikiran Islam (Jakarta: Islamic Research Center, 1970). There have been a rather large number of published responses over the years. 
significant above all for the degree to which it showed that Islam had already been deeply affected by the realities of the post-Sukarno era. Basically these were that Islam had been freed from the black-or-white, sycophant-or-enemy roles in which it had been trapped during Guided Democracy and forced to come to terms with a government more willing to compromise on Islamic issues than its predecessor but less inclined to share political power ${ }^{83}$ Some of the results were rapidly changing forms of Islamic education, and a burgeoning Moslem presence in mass-media fields such as magazine and book publishing . . and mass entertainment.

All of this suggests that the New Order and the society to which it has given rise are not as rigid or polarized as they have frequently been portrayed. A common assumption, for example, has been that what looks like a distinct authoritarian drift in government has been accompanied by a similar tightening in other areas, including the social and cultural, but there is some reason to reconsider this idea. This is not to say that the New Order has always been comfortable with the pace and content of the changes occurring under its aegis. That curious slogan of the Suharto era, "stability with dynamism," 84 reveals an underlying concern with potential disorder and unpredictable effects of rudderless change; the notion of the "floating mass" 85 implies not merely a protective posture towards, but a certain uneasiness about, the bulk of the population. Jakarta has not, however, shown a propensity for meddling in pop culture affairs, which it certainly sees in a different light from "serious" or "real" art, especially literature, leaving it, and especially the dangdut style, free to develop.

In some respects this situation is encouraging, but from at least one perspective there is some cause, I think, for concern. If government has generally let popular culture flourish unattended, it has also remained relatively ignorant of what its significance may be. Popular culture, arguably now a strong reflection of at least some aspects of that social phenomenon, has gone ignored, and dangdut particularly so. I have yet to meet, for example, a government official who has seen--or will admit to having seen--an Oma Irama film; most treat his music as bizarre and not a little pathetic. If the dangdut style is leaving anything in its wake, it would appear to be the beginnings of a lasting populist sensitivity in viable modern cultural forms. ${ }^{86}$ And this may foreshadow further social changes which the government in this increasingly politically centralized nation may be unprepared to comprehend.

83. On Islam in the Guided Democracy period, see Ahmed Syafii Maarif, "Islamic Politics under Guided Democracy in Indonesia, 1959-1965" (M.A. thesis, Ohio University, 1980). On the changes during the New Order, see Donald K. Emmerson, "Political Impasse, Cultural Opportunity: Islam in Indonesia" (Paper presented at the conference on "World Islam from Morocco to Indonesia," Washington, D.C., June 1980).

84. The phrase appears several times, for example, in Suharto's State of the State message for 1980. Kompas, August 17, 1980.

85. The notion of the floating mass is elucidated in Ali Murtopo, Some Basic Thoughts on the Acceleration and Modernization of 26 Years' Development (Jakarta: CSIS, 1973).

86. Dangdut may well be on the decline, as suggested for example in "Film Dangdut Merosot?" Vista, 507 (May 1980), pp. 6-7; but similarly populist forms appear to be taking its place. Thus the current jaipongan craze, which has taken a Sundanese village dance and rhythm and turned them into a popular big-city fad. See Tempo, 11, 45 (January 9, 1982), p. 60; 12, 3 (March 20, 1982), p. 26; and 12, 25 (August 21, 1982), p. 23. Also Zaman, 3 (April 25-May 1, 1982), p. 23. 